\title{
A Review on Microbial Fuel Cells
}

\author{
Baidaa A. Kitafa ${ }^{a^{*}}$, Afaf J. Obaid Al-saned ${ }^{\mathrm{b}}$ \\ ${ }^{a}$ Civil Engineering Department, University of Technology,Baghdad,Iraq. \\ 42124@sstudent.uotechnology.edu.iq

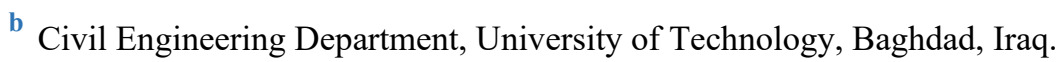 \\ 40359@uotechnology.edu.iq \\ *Corresponding author.
}

$\begin{array}{lll}\text { Submitted: 29/12/2019 Accepted: 01/04/2020 Published: 25/01/2021 } & \text { Act }\end{array}$

\section{K E Y W OR D S A B S T R A C T}

Microbial Fuel Cell

Microorganisms

Electricity Substrate

Wastewater Treatment

\begin{abstract}
The Microbial Fuel Cell (MFC) is a bioreactor with which the chemical energy in chemical bonds of organic compounds are converted to electricity under anaerobic conditions through catalytic reactions of micro-organisms. It has been familiar for a long time that electricity can be generated directly through using bacteria to break organic matter. A microbial fuel cell can also serve in different wastewater treatment to destroy organic matter. The development of MFC technology requires a greater understanding of the microbial processes for MFCs, and their components, limitations, factors and design this system, to be simpler and large scale system developed; so that it would increase electricity production while being cost-effective. This review discusses, what is the MFCs and the basic principle of how MFC operate, the most essential $M F C$ components and their relevance, multiple MFC designs that have been presented as efficient configurations, Applications of MFCs, and several types of wastewater as substrates in MFC also highlighted.
\end{abstract}

How to cite this article: B. A. Kitafa, A. J.Obaid "A Review on Microbial Fuel Cells," Engineering and Technology Journal, Vol. 39 , Part A, No. 01, pp. 1-8, 2021.

DOI: https://doi.org/10.30684/etj.v39i1A.1518

This is an open access article under the CC BY 4.0 license http://creativecommons.org/licenses/by/4.0

\section{INTRODUCTION}

One of the most important challenges facing the world at the present time is energy problems due to the depletion of energy sources represented by fossil fuels and global warming. Therefore, it has become important to find alternative and renewable sources of energy [1]. MFC is new and promising technology through which electricity is produced during pollutants are removed from wastewater[2]. MFC is an electrochemical biological system that works to convert the potential energy contained within the bounds of organic matter that is degradable by microorganisms into clean electrical energy. The MFC cells, as compared to other conventional technologies of wastewater handling such as activated sludge, have the advantages of electricity production, reducing the cost of the operation due 
to passive oxygen diffusion to the cathode (no wastewater aeration) and reduce the sludge generation. This paper aims to review on use of different wastewaters in MFC, the current knowledge of microbiology in the production of electrical power, as substrates in MFC the methods and materials used to construct this technology, and the applications of MFC.

\section{History of Microbial Fuel Cell}

The year 1910 witnessed the first thought of generating energy from bacteria with Michael C. Potter, a botany professor at the University of Durham, UK, where he presented a description of cultures of yeast and Escherichia coli from which electricity was produced. That was the first observation of the biological process generating bioelectricity [3].

However, the idea of electrical energy generated by microorganisms did not gain much interest until 1980, when it was found that the current density and power output could be greatly improved by adding chemical electron transfer mediators in MFC reactors [4]. .

Many research have studied the efficiency of MFC in generating energy and wastewater treatment. [5], he supplied the MFC with a compartment of zeolite packed anodic and a cation exchange membrane (CEM) for the isolate the cathode from the anode. The operation of the presented MF cell was assessed in terms of the generation of power due to the bacterial consortium activities in the biofilm mobilized on the zeolite bearer and the removal of COD. It was concluded from the results that the power density, the efficiency of COD removal, and the current density were $2.4 \mathrm{~mW} / \mathrm{m} 2,66 \%$, and $10 \mathrm{~mA} / \mathrm{m} 2$. respectively.

[6] examined the lab -scale MFC system performance with volume of $45 \mathrm{~L}$ consisting of four single compartment membrane-less MFCs integrated with a full-scale wastewater handling plant. The integrated system was operated under practical conditions with the effluent of the primary clarifier for nine months to determine the best operational strategy for maximum energy generation and stable power output. Results showed that COD, TSS, nitrogen removal, and columbic efficiency of $24.8 \%$ of $24 \%, 40 \%$ and $28 \%$, respectively were achieved.

Constructing and testing a microbial fuel cell, (MFC) was accomplished by [7], she was operated and studied two chambers MFC connected with salt bridge using synthetic and real wastewater as anode chamber solution. Operating temperature and $\mathrm{pH}$ values were investigated by changing temperatures from $25 \mathrm{C}$ to $30 \mathrm{C}$ and varying $\mathrm{pH}$ from 6.7 to 6.5 . The results revealed that increasing operation temperature had a significant effect on reducing operation time while decreasing $\mathrm{pH}$ improved the measured voltage and current besides reducing operation time to just five days. The COD reduction rate was above $60 \%$ indicated the ability to live microorganisms in digesting the wastewater producing electrical power with maximum values of $0.443 \mathrm{mV}$ and $8.3 \mu \mathrm{A}$ for voltage and current, respectively.

\section{MicRobial FUEL CELLS}

A microbial fuel cell (MFC) is a bioreactor device that generates electrical power from chemical energy in the present chemical bonds of the organic compounds under anaerobic conditions through catalytic reactions of microbes. It has been familiar for several years that the generation of electricity directly through the use of bacteria to break down organic substrates is possible [8]. This means that MFC is a bioelectric transformer that obtains electricity from organic matter [9]. Figure 1 shows a simple microbial fuel cell setup[10] 


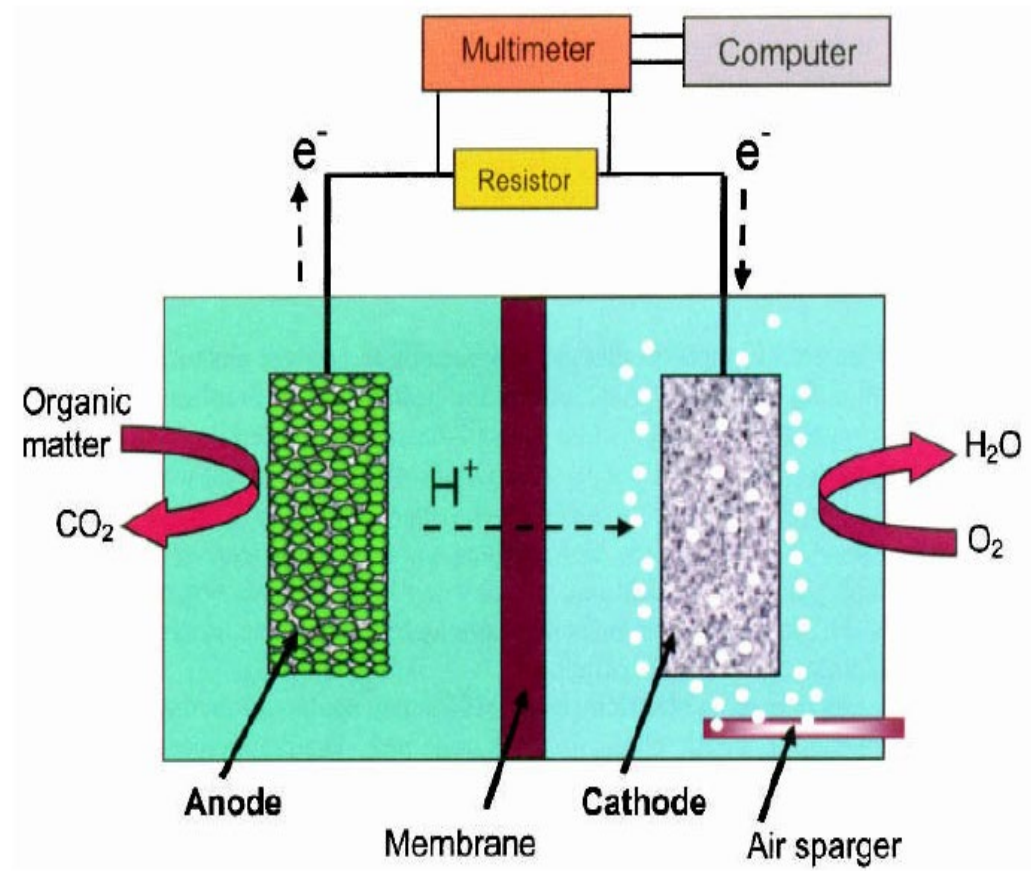

Figure 1: Microbial fuel cell [10]

\section{Microbial fuel cells components}

The most important basic components of MFC are listed below and as shown in the table (1):

1) Electrodes - for both (anode and cathode) in the compartments of anode and cathode

2) Proton Exchange Membrane - (Nafion is widely employed as the membrane of least resistance)

3) Substrate - any organic matter employ as the source of energy for microbes i.e. wastewater

4) Bacteria - exoelectrogens, more suitable for most of MFC applications

The latest MFC developments focus on optimizing each aspect to increase the overall efficiency of the electrochemical device.

TABLE I: Basic Comparison for Microbial Fuel Cells [4]

\begin{tabular}{ccc}
\hline \hline Items & Materials & Remarks \\
\hline Anode & $\begin{array}{c}\text { Graphite, graphite felt, carbon paper, carbon-cloth, Pt, Pt } \\
\text { black, reticulated bitreous carbon (RVC) }\end{array}$ & Necessary \\
\hline Cathode & $\begin{array}{c}\text { Graphite, graphite felt, carbon paper, carbon-cloth, Pt, Pt } \\
\text { black, (RVC) }\end{array}$ & Necessary \\
\hline Anodic Chamber & Glass, polycarbonate, Plexiglass & Necessary \\
\hline $\begin{array}{c}\text { Proton Exchange } \\
\text { Membrane (PEM) }\end{array}$ & Glass, polycarbonate, Plexiglass & Optional \\
\hline Electrode Catalyst & $\begin{array}{c}\text { Nafion, Ulterx, polyethylene.poly (styrene-co- } \\
\text { divinylbenzene); salt bridge, porcelain septum or solely } \\
\text { electrolyte }\end{array}$ & Necessary \\
\hline & Pt, Pt black, MnO2, Fe3+, polyaniline, electron mediator \\
immobilized on the anode & Optional \\
\hline
\end{tabular}

\section{Working of MFCs}

The MFC system consisting of an anode (anaerobic) and cathode (aerobic) compartment, connected by an external circuit and separated by proton exchange membrane (PEM).. The anode compartment consists of microorganisms (catalysts) and anode (electrode), and can be fueled with wastewater (synthetic or real) as substrate and in some times need to redox mediator (not required in the case of mediator -less MFC). Typically, microbes in MFC are used to digest the substrate 
(organic matter) in anode compartment and release the electrons. Later, and through the external wires, the electron transfer to the cathode [11].

The protons diffuse through the proton exchange membrane (which separates cathode and anode chamber) into cathode chamber in which combined with $\mathrm{O}_{2}$ to form $\mathrm{H}_{2} \mathrm{O}$ [12]. The two-half and the overall oxidation/reduction reactions with the use of monosaccharide (e.g. glucose) as the organic matter are illustrated in the equations below:

Anodic reaction (oxidation half-reaction):

$$
\mathrm{C}_{6} \mathrm{H}_{12} \mathrm{O}_{6}+\mathrm{H}_{2} \mathrm{O}=6 \mathrm{CO}_{2}+24 \mathrm{e}^{-}+24 \mathrm{H}^{+}
$$

The cathodic reaction (reduction half-reaction):

$$
\mathrm{O}_{2}+4 \mathrm{e}^{-}+4 \mathrm{H}^{+}=2 \mathrm{H} 2 \mathrm{O}
$$

Overall oxidation/reduction reaction:

$$
\mathrm{C}_{6} \mathrm{H}_{12} \mathrm{O}_{6}+6 \mathrm{O}_{2}=6 \mathrm{CO}_{2}+6 \mathrm{H}_{2} \mathrm{O}
$$

\section{The microorganisms used in MFC}

In the past, it was believed that there only a few microorganisms empyloed to produce electricity. Recently, it was noticed that a large number of microorganisms cloud be used in MFC [13]. Understanding some of the basic functions of bacteria is important to facilitate understanding of the basic function of MFCs. In principle, organic matter is broken down by bacteria, as a result, energy is released into the body processing. The focus will be on some bacteria that can generate electricity and effectively transfer electrons in the anode. This bacteria is named as Exoelectrogens. Exoelectrogenic bacteria are the most suited according to their ability to transport electrons outside of the cell. The current kind of bacterial can be empyloed in a mediator-less MFC, in which a 'mediator' that assists in the electron transfer is unrequired [4]. A list of tested microbial and their

\begin{tabular}{|c|c|c|}
\hline The Microbes & Substrate & Applications \\
\hline Streptococcus lactis & Glucose & Ferric chelate comples as mediators [14]. \\
\hline $\begin{array}{l}\text { Shewanella } \\
\text { oneidensis }\end{array}$ & Lactate & Mediator [15]. \\
\hline $\begin{array}{l}\text { Shewanella } \\
\text { putrefaciens }\end{array}$ & $\begin{array}{l}\text { Lactate, puruvate, } \\
\text { acetate, glucose }\end{array}$ & $\begin{array}{l}\text { Mediator-less MFC but incorporating an electron } \\
\text { mediator like Mn(IV) or NR into the anode enhanced } \\
\text { the electricity production [16]. }\end{array}$ \\
\hline $\begin{array}{l}\text { Yeast } \\
\text { (saccharomyces } \\
\text { cerevisiae) }\end{array}$ & Glucose & Mediator-less MFC [7]. \\
\hline \multirow[t]{2}{*}{$\begin{array}{l}\text { Aeromonas } \\
\text { hydrophila }\end{array}$} & Glucose & $\begin{array}{l}\text { Glucose Neutral red or thionin as electron mediator } \\
\qquad[16] .\end{array}$ \\
\hline & Acetate & Mediator-less MFC [17]. \\
\hline $\begin{array}{l}\text { Clostridium } \\
\text { butyricum }\end{array}$ & $\begin{array}{l}\text { Starch, glucose, } \\
\text { lactate, molasses }\end{array}$ & Sulphate and Sulphate as mediator [18]. \\
\hline Escherichia Coli & Sucrose & Mediators such as methylene blue needed [19]. \\
\hline $\begin{array}{c}\text { Geobacter } \\
\text { sulfurreducens }\end{array}$ & Acetate & Mediator-less MFC [20]. \\
\hline $\begin{array}{l}\text { Pseudomonas } \\
\text { aeruginosa }\end{array}$ & Glucose & $\begin{array}{l}\text { Pyocyanin and Phenazine-1- carboxamide as Mediator } \\
{[21] .}\end{array}$ \\
\hline Klebsiella pneumonia & Glucose & $\begin{array}{l}\text { HNQ as mediator biomineralized manganese as } \\
\text { electron acceptor [22]. }\end{array}$ \\
\hline
\end{tabular}
associated substrates used in MFC are shown in Table (2).

TABLE II: Different Microbial and Their Associated Substrates 


\section{DESIGN OF THE MICROBIAL FUEL CEELS}

Various types and designs of biofuel cells have been developed to demonstrate MFCs efficiency and reduce limitations in system units. Electrodes, wires, glass cells, membrane, and a salt bridge have an essential role in building the MFCs. The MFC types based on its configuration and mode of operation includes [23].

\section{Double-Chamber MFCs:}

Two-chambered MFCs is a typical and preferred MFC design, which mainly consist of an anode and cathode compartment separated proton exchange membrane (PEM) or by a salt bridge, through which the protons move toward the cathode [24]. The anode chamber remains free of oxygen for the occurrence of the anaerobic breakdown process, which is usually purged with nitrogen. Anode chamber contains microbes, substrate, and electrode whereas the cathode chamber contains electrode, freshwater, and oxygen supply [25].

\section{Single-Chamber MFCs}

This type of MFCs has only single compartment that contains both anode and the cathode .Singlechamber MFCs combine both electrodes, the anode and the cathode, without a proton exchange membrane (PEM). They normally possess only an anodic chamber without the requisite of aeration in a cathodic chamber. The single-chambered MFC is a simple and cost-effective design and may have various shapes of compartments, which have been reviewed in various studies.

\section{Stacked MFCs:}

It is a kind of construction in which (MFC) is connected in either a parallel or a series connection [26]. MFC may be stacked through making various configurations of both hydraulic flow as well as electrode. Accordingly, four types of configurations can be found:

1) parallel electrode connections in parallel flow mode .

2) series electrode connections in series flow mode.

3) parallel electrode connections in series flow mode.

4) series electrode connections in parallel flow mode .

\section{Up-flow microbial fuel cell:}

The tubular-shaped MFCs is made of a cathode and an anode (top and bottom) with a glass wall separator and glass beads Layers. Nutrition is provided from below the anode, passes over the cathode and goes upward. The gradient for the proper operation of MFCs is provided by the diffusion barrier placed between electrodes [27].

\section{APPLICATIONS OF MICROBIAL FUEL CELLS}

\section{Wastewater management}

Microbial fuel cells are sustainable developed devices for treating the wastewater. Wastewater is used as the substrate in these cells, and it produces both electrical energy and other value-added products simultaneously. The MFC design is being studied by various researchers throughout the world, along with different wastewaters as basic material, many results are found in terms of enhancing the density of power, COD removal, coulombic efficiency, and the effectiveness of substrates concentration on loading rate, etc. Various forms of wastewater are being used in MFC, like complex and undefined or simple or defined wastewaters [28]. The substrates or wastewater for the cells of MF are presented in Figure 2. 


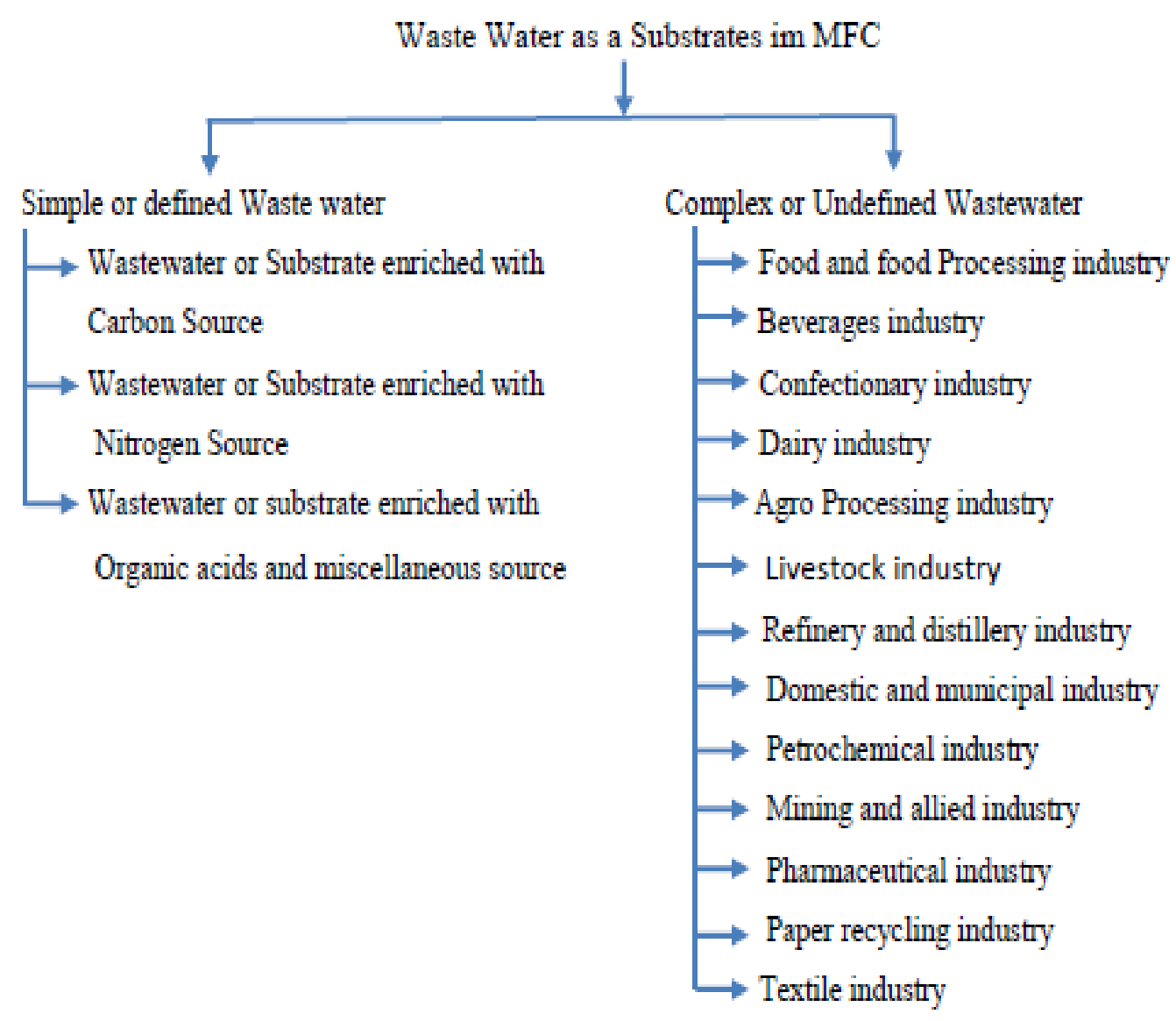

Figure 2: Wastewater or substrates for MFCs[29]

\section{Electric power-generating}

Microbial fuel cells can substitute chemical energy that exists within the chemical compounds with biomass to electric power aided by catalysts (microorganisms), because the chemical energy for the oxidation of the fuel molecules is directly altered to electrical power instead of heat even though power production relatively low [30].

\section{Production of Secondary Fuel}

Secondary fuels such as hydrogen (H2) can be produced as a second source of electrical power from microbial fuel cells through a minor and simple modification. When standard experimental conditions are provided, the electron and proton produced in the anaerobic chamber are transferred to the cathode which creates with $\mathrm{O}_{2}$ to form water [31]. Generating hydrogen (H2) through performing modification on MFC compounds on organic waste can form an interesting alternative. In these devices, the cathode chamber will maintain anaerobic status, as well as applying an additional voltage of 0.23 volts or more to the cathode [32]. Under these circumstances, protons are reduced to hydrogen in the cathode.

\section{Biosensors}

MFCs can be widely used in the biological sensors field to assess the level of contaminants in many wastewater liquid wastes. The technology of MFC is one method of those used to measure the demand for biological oxygen of various waste treatment plants. This kind of BOD sensor has excellent operational sustainability [23]. 


\section{CONCLUSION}

This review provided background information on MFC technology, substrate use from various sources as fuels, MFC designs, various microorganisms used in MFC and MFC applications. MFC is a wastewater treatment and energy recovery technology. MFCs can be incorporated into treatment plants rather than a stimulant sludge process that reduces the cost of treatment. In the future, the efficiency, energy density, and reliability of MFCs are expected to increase. Thus, one can make use of it as a source of energy and renewable energy sources such as hydrogen, methane, and generation of electricity. Sensors to detect impurities present in the water source can be designed by using this technology.

\section{References}

[1] E. Elakkiya, Comparison of anodic metabolism in bioelectricity production during treatment of dairy wastewater in microbial fuel cell, Bioresour. Technol., 136 (2013) 401-412. https://doi.org/10.1016/j.biortech.2013.02.113

[2] N. Samsudeen and T. K. Radhakrishnan, Bioelectricity production from microbial fuel cell using mixed bacterial culture isolated from distillery wastewater, Bioresour. Technol., 195(2015) 242-247. https://doi.org/10.1016/j.biortech.2015.07.023

[3] Bullen, R. A., Arnot, T. C., Lakeman, J. B., Walsh, F. C ., Biofuel cells and their development, Biosens. Bioelectron ., 21(2006) 2015-2045 . https://doi.org/10.1016/j.bios.2006.01.030

[4] Du Z, Li H, Gu T, A state of the art review on microbial fuel cells:A promising technology for wastewater treatment and bioenergy, Biotechnol Advs., 25(2007) 464-482.

[5] Ali A., Zainab Z, Pharmaceutical Wastewater Treatment Associated with Renewable Energy Generation in Microbial Fuel Cell Based on Mobilized Electroactive Biofilm on Zeolite Bearer , J. Eng., 21(2015) 35-44. https://doi.org/10.31026/j.eng.2015.07.03

[6] Hiegemann, H., Herzer, D., Nettmann, E., Lübken, M., Schulte, P., Schmelz, K., Gredigk-Hoffmann, S., Wichern, M., An integrated 45L pilot microbial fuel cell system at a full-scale wastewater treatment plant, Bioresour. Technol., 218(2016) 115-122. https://doi.org/10.1016/j.biortech.2016.06.052

[7] Afaf Jadaan obeid. Constructing and operation of two chamber fuel cellunder synthetic and real wastewater with different operation conditions, Iraqi Journal of Civil Engineering 12(2018)67-74. http://dx.doi.org/10.37650/ijce.2018.142409

[8] Logan E. , Simultaneous Wastewater Treatment and Biological Electricity Generation, Water Sci. Technol., 52(2005) 31-37.

[9] Roy S, Marzorati S, Schievano A, Microbial fuel cells, ESST., 1(2017) 245-259. http://dx.doi.org/10.1016/B978-0-12-409548-9.10122-8

[10] B.E. Logan Microbial Fuel Cells, John Wiley Sons, 2008.

[11] V.C. Kalia, P. Kumar (eds.), Microbial Applications, (C) Springer International Publishing AG, Vol.1.

[12] Venkata Mohan S, Velvizhi G, Annie Modestra J, Srikanth S Microbial fuel cell: Critical factors regulating bio-catalyzed electrochemical process and recent advancements, Renew. Sust. Energ. Rev., 40(2014) 779-797. http://dx.doi.org/10.1016/j.rser.2014.07.109

[13] Davis F, Higson SP, Biofuel cells-recent advances and applications, Biosens. Bioelectron., 22(2007) 1224-35. https://doi.org/10.1016/j.bios.2006.04.029

[14] Vega CA, Fernandez I, Mediating effect of ferric chelate compounds in microbial fuel cells with Lactobacillus plantarum, Streptococcus lactis, and Erwinia dissolvens, Biosens. Bioelectron., 17(1987) 217 22.

[15] Ringeisen BR, Henderson E, Wu PK, Pietron J, Ray R, Little B, High power density from a miniature microbial fuel cell using Shewanella oneidensis DSP10, Environ. Sci. Technol., 40(2006) 2629- 2634. https://doi.org/10.1021/es052254w

[16] Park DH, Zeikus JG, Improved fuel cell and electrode designs for producing electricity from microbial degradation, Biotechnol. Bioeng ., 81(2003) 348-355. https://doi.org/10.1002/bit.10501 
[17] Pham CA, Jung SJ, Phung NT, Lee J, Chang IS, Kim BH, A novel electrochemically active and Fe (III)reducing bacterium phylogenetically related to Aeromonas hydrophila, isolated from a microbial fuel cell, FEMS ., 223(2003) 129-34. https://doi.org/10.1016/s0378-1097(03)00354-9

[18] Niessen J, Schroderm U, Scholz F, Exploiting complex carbohydrates for microbial electricity generation a bacterial fuel cell operating on starch, Electrochem. commun., 6(2004) 955-958. https://doi.org/10.1016/J.ELECOM.2004.07.010

[19] Schroder U, Niessen J, Scholz F, A generation of microbial fuel cells with current outputs boosted by more than one order of magnitude, Angew. Chem. Int.Ed. Engl., 42(2003) 2880-2883. https://doi.org/10.1002/anie.200350918

[20] Min B, Cheng S, Logan BE, Electricity generation using membrane and salt bridge microbial fuel cells, Water. Res., 39(2005) 1675-86. https://doi.org/10.1016/j.watres.2005.02.002

[21] Rabaey K, Boon N, Siciliano S, Verhaege M, Verstraete W, Biofuel cells select for microbial consortia that self-mediate electron transfer. Appl. Environ. Microbiol ., 70(2004) 5373-5382.

[22] Menicucci J, Beyenal H, Marsili E, Veluchamy RA, Demir G,Lewandowski Z, Procedure for determining maximum sustainable power generated by microbial fuel cells,Environ. Sci.Technol., 40(2006)1062-8. https://doi.org/10.1021/es0511801

[23] Kim BH, Chang IS, Gil GC, Park HS, Kim HJ , Novel BOD sensor using mediator-less microbial fuel cell, Biotechnol. Lett., 25(2003) 541-545. https://doi.org/10.1023/a:1022891231369

[24] Pant D, Van Bogaert G, Diels L, A review of the substrates used in microbial fuel cells (MFCs) for sustainable energy production, Bioresour. Technol., 101(2010)1533-1543. https://doi.org/10.1016/j.biortech.2009.10.017

[25] B. Logan, S. Cheng, V. Watson, and G. Estadt, Graphite Fiber Brush Anodes for Increased Power Production in Air-Cathode Microbial Fuel Cells, Environ. Sci. Technol., 41(2007) 3341-3346. https://doi.org/10.1021/es062644y

[26] Aelterman P, Rabaey K, Pham HT, Boon N, Verstraete W. Continuous electricity generation at high voltages and currents using stacked microbial fuel cells, Environ, Sci. Technol., 40(2006) 3388-3394. https://doi.org/10.1021/es0525511

[27] Schwartz K, Microbial fuel cells: Design elements and application of a novel renewable energy sources, Enzyme. Microb. Technol., 47(2007) 179-188.

[28] Lee D-J, Chang, J-S, Lai J-Y., Microalgae-microbial fuel cell: a mini review, Bioresour. Technol., 198 (2015)891-895. https://doi.org/10.1016/j.biortech.2015.09.061

[29] H.M. Singh, A.K. Pathak, K. Chopra, V.V. Tyagi, S. Anand ,Microbial fuel cells: a sustainable solution for bioelectricity generation and wastewater treatment, Informa UK Limited, trading as Taylor Francis Group ,Biofuels, 10 (2019)11-31. http://dx.doi.org/10.1080/17597269.2017.1413860

[30] Ieropoulos I, Greenman J, Melhuish C, Imitation metabolism: energy autonomy in biologically inspired robots , Proceedings of the 2nd international symposium on imitation of animals and artifacts, (2003) 191-4. https://orcid.org/0000-0002-9641-5504

[31] Surajit Das and Neelam Mangwani, Recent developments in microbial cells: a review, J. Sci. Ind. Res., 69 (2010) 727-731.

[32] B.E. Logan Microbial Fuel Cells, John Wiley Sons, 2008 